\title{
An Analysis of English Word Choice and Grammatical Errors in Thai Novel Translation of Matthayomsuksa VI Students at Panyaworakun School
}

\author{
Thoseporn Sophitthammakun \\ Foreign Languages Department, Panyaworakun School, SESAO 1, Thailand \\ * E-mail of the corresponding author: Thosepornssophitthammakun@gmail.com
}

\begin{abstract}
The research entitled "An Analysis of English Word Choice and Grammatical Errors in Thai Novel Translation of Matthayomsuksa VI Students at Panyaworakun School" contains 11 populations. This study was conducted by using the Grammar-Translation Method to study word choices and grammar in translating the assigned novel extract of 11 Matthayomsuksa 6/4 students in the English-Japanese Program and analyze the problems found in the translation works produced by each and all students in this classroom. The research instruments were a Wo. Winitchaikun's novel extract "Burapha" and the translation works of the extract made by each of 11 Matthayomsuksa 6/4 students. The students' translation works were analyzed by consulting the 3 English grammatical books as follows: 1. English Grammar in Use, 2. Prentice Hall Writing and Grammar: Communication in Action Bronze Level, and 3. Advanced English Grammar for High Learner.The research results revealed that in translating and writing English, mostly, 11 Matthayomsuksa 6/4 students made errors in the first 5 sequences of the following problematic points: 1.11 points or $15.94 \%$ of Missing Some Words, 2. 10 points or $14.49 \%$ of Word Choice, 3.9 points or $13.04 \%$ of Capital and Small Letters, 4.7 points or $10.14 \%$ of Tense and Full Stop ( . ) which also has the same 7 points or $10.14 \%, 5.4$ points or 5.80\% of Sentence Parts. Therefore, to improve 11 high-school students of Matthayomsuksa 6/4 in the English-Japanese Program, the teacher-researcher should develop the students in these first 6 problematic points which the students made the most in the first 5 sequences.
\end{abstract}

Keywords: The Grammar-Translation Method, An Analysis of English Word Choice and Grammatical Errors, The Students' Translation Works

DOI: $10.7176 / \mathrm{JEP} / 12-15-02$

Publication date:May $31^{\text {st }} 2021$

\section{Introduction}

English is a universal language and has been used in every corner of the world. English is everywhere in our daily lives such as advertisements, drug labels, food labels, manuals, articles, news reports, TV commercials, traffic signs, computer games, textbooks, etc. According to teaching E33202: Reading and Writing English 6 and E33204: Thematic English 6 using Cognitive Code Learning Theory consisting of an explanation of the rule, exercises, and the communicative competence section, the instruction did not succeed because in the stage of an explanation of the rule, every time the teacher-researcher categorized and explained words and grammar, the students slept. The instruction was useless as it might be expected.

One day, in Class 6/4 which was the art students in the English-Japanese Program, the teacher-researcher met Japanese texts following with translated texts as well as each student's name at the end of each translated text on the whiteboard written and taught by Sensei, a non-native Japanese teacher. Meeting these texts on the whiteboard was regarded as informal education. The teacher-researcher learned Sensei's teaching technique by way of informal and incidental learning. Therefore, to follow Sensei, the teacher-researcher used the GrammarTranslation Method so that the students learned in the same familiar way of both Japanese and English subjects. There is a variety of teaching techniques. One of the teaching techniques successfully used in Thailand is the Grammar-Translation Method. Although this teaching technique is a traditional method, this method is still useful for Thai teachers to assist the students to learn the language.

In New Weaving It Together 3 Teacher's Guide, Unit 2: Customs that contains the theme/ topic: Cultures is by a classroom activity, translating a Wo. Winitchaikun's novel extract "Burapha" into English which once was an admission examination of translation section in the field of English at the Faculty of Arts, Chulalongkorn University in the year 2009. The benefits of these research results can raise teachers' and students' awareness of the problematic points of word choices and grammar. These findings will enable the teacher-researcher to help Matthayomsuksa 6/4 students learn English more effectively and enable Matthayomsuksa 6/4 students to especially pay attention to and focus on learning about English word choices and grammar more. Particularly, this research can be a guideline for language teachers to teach English with the Grammar-Translation Method. 


\section{Review of Literature}

The teacher-researcher reviews a related past study for this present research as follows.

Nantana Sittirak (2015: 30-47) researched "Grammar-Translation Method in an EFL Class in Thailand: A Glance at an English Song's Lyrics" to study students' word choices in translating the assigned lyrics and their translation at sentence-level and analyze the problems found in the translation work produced by 23 high-school students, aged 16-18, who studied the "English through Modern Media", a topic taught at the "English Is Everywhere" project organized by the Languages Department, Faculty of Commerce and Management, Prince of Songkla University, Trang Campus. Each of the students is assigned to translate the song hook "Heal the world" into Thai; they are given 20 minutes to complete the task and allowed to use a bilingual dictionary. The data obtained from the translation works are studied and analyzed, with focuses on the students' word choices and their translation at the sentence level. The research results revealed that despite being allowed to use a bilingual dictionary, the students still made mistakes both at word level and sentence level, thus reflecting their vocabulary and grammatical incompetency as well as ineffective reading skills. Hence, the use of the Grammar-Translation Method through numerous classroom activities, for example, translating song lyrics, can still be done in Thailand to enable the teacher to study problems in learning English among Thai students and to provide appropriate assistance concerning the problematic grammar and vocabulary points they have.

Megawati Megawati (2017: 95-108) stated in "The Improving Students' Reading Comprehension through Grammar Translation Method" that the Grammar-Translation Method can improve the students' reading comprehension at SMK Private TaposDepok. To improve 33 tenth grade students, proving hypothesis needs the data collected by classroom observation, interview, and students' test by way of the 3 cycles of the classroom action research. Each cycle consists of four steps: 1. Planning action, 2. Implementation of the action, 3 . Observation, and 4. Reflection. The analysis of the research data showed that students' reading comprehension ability through the Grammar-Translation Method improves significantly with average in cycle I, II, and III. Cycle I average score is 6.76 or $60 \%$. Cycle II average score is 7.35 or $78 \%$. Cycle III average score is 7.8 or $100 \%$. The results also revealed that the students could answer the question and they can read the text fluently. Therefore, it is proved that the Grammar-Translation Method is effective in improving students' reading comprehension. The researcher suggested that students be active to practice reading from the kind of material given by teachers and some information from mass media to get better results in learning English.

Saber Ahmed Hago Eisa (2020: 381-392) indicated in "The Pros and Cons of the Grammar Translation Method on the Performance of Saudi EFL Learners" that to explain the deficiency and the limitations of the Grammar-Translation Method as a language teaching method and to find out whether the Grammar-Translation Method has any advantages to the Saudi secondary school learners, concerning Literature Review of Eisa's study, the biggest advantage of this method is understanding the phraseology such as abstract words, idioms, phrases, metaphors, similes, etc. because translation is possible in this method. For this reason, students can have a better understanding of complicated concepts. The language of students and teachers does not hamper the communication gap due to teaching and learning in their mother tongue. This method is useful from this aspect that students are taught grammatical rules deductively. Consequently, students can improve and write correct sentences. Students are taught books in their mother tongue which they may have a better command than other students. This method requires few specialized skills on the part of teachers, so anyone can teach. However, the disadvantages of the Grammar-Translation Method are that students do not participate actively in the classroom. Communication is not much focused and very little attention is paid to content. The focus is made on translation which is sometimes misleading. The analysis of the research data from the questionnaire of 35 secondary school English teachers selected randomly found that:

1. Bad effect of this method is on student's motivation. Because he or she cannot succeed in learning the difficult grammar rules of the target language. That leads to boredom in the classroom.

2. Students cannot master all the four skills of English (listening, speaking, reading, and writing).

3. The Grammar-Translation Method is the easiest for a teacher to employ. It doesn't require a teacher to speak good English or make good lesson preparations. So, his knowledge might be lost into oblivion.

Unlike Eisa (2020: 381-392)'s study, a questionnaire was not employed for collecting and analyzing the data in this present study. Also, this present research does not improve or develop students with the GrammarTranslation Method as Megawati (2017: 95-108)'s classroom-based research or classroom action research; on the contrary, this present research aims at analyzing English word choice and grammatical errors with the Grammar-Translation Method. Among the three studies in terms of research methodology, this present study is similar to the past research of Nantana Sittirak (2015: 30-47). The different things from the past research of Nantana Sittirak (2015: 30-47) are that this present research is studying word choices and grammar in translating a novel extract which 11 high-school students of Matthayomsuksa 6/4 who study in the English-Japanese Program at Panyaworakun School translate from Thai to English. Each student ordering from their numbers is assigned to translate each text of a Wo. Winitchaikun's novel extract "Burapha" into English and their translation work from number 1 to number 11 are analyzed to find their problematic points in word choices and 
grammar.

\section{Research Objectives}

1. To study 11 high-school students of Matthayomsuksa 6/4's word choices and grammar in translating the assigned texts into English of a Wo. Winitchaikun's novel extract "Burapha".

2. To study and analyze the problematic points found in the translation works from Thai to English of a Wo. Winitchaikun's novel extract "Burapha” produced by 11 high-school students of Matthayomsuksa 6/4.

\section{Research Methodology}

\subsection{Population}

The population in this study was 11 high-school students of Matthayomsuksa 6/4 who studied in the EnglishJapanese Program at Panyaworakun School. The students studied E33202: Reading and Writing English 6 and E33204: Thematic English 6 and in Unit 2: Customs which contains the theme/ topic: Cultures of E33202: Reading and Writing English 6, the students learned a classroom activity, translating of a Wo. Winitchaikun's novel extract "Burapha" into English.

\subsection{Materials}

4.2.1. A Wo. Winitchaikun's novel extract "Burapha" (See Appendix A and B)

4.2.2. The translation works from Thai to English of a Wo. Winitchaikun's novel extract "Burapha" produced by 11 high-school students of Matthayomsuksa 6/4.

\subsection{Data Collection}

4.3.1. 11 high-school students of Matthayomsuksa 6/4 were assigned to read a Wo. Winitchaikun's novel extract "Burapha".

4.3.2. Each student from number 1 to number 11 translated each text in the sequence of the extract into English as well as writing their names in order after each translated text on the whiteboard.

4.3.3. The teacher-researcher wrote down all texts translated and written on the whiteboard by the students from number 1 to number 11 so that the teacher-researcher could check each student's translation work.

\subsection{Data Analysis}

Consulting the 3 English grammatical books which were 1. English Grammar in Use, 2. Prentice Hall Writing and Grammar: Communication in Action Bronze Level, and 3. Advanced English Grammar for High Learner, the teacher-researcher analyzed the students' word choice and grammatical errors from checking the students' translation works.

\section{Results}

The results of the study obtained from the translation work from Thai to English of a Wo. Winitchaikun's novel extract "Burapha" which was produced by 11 high-school students of Matthayomsuksa 6/4 is reported below.

Text 1 in Thai: แคธรีนวาดภาพว่าที่ แพของจัสติ นคง จะเงียบ เชียบเหมือนครั้งก่อนที่ เธอ เคยมาหา แต่ก็กลับพบว่ามันเต็มไปด้วยผู้คนบริวารของเขา หมอบเฝ้ารอรับอยู่ตั้งแต่ก้าวแรกที่เธอขึ้นจากเรือเลยทีเดียว

Text 1 in English: Katherine imagined that at Justine's raft, it might be as quiet as the time she had been before, but she found out that the raft was crowded with servants squatting and waiting to greet her while she was taking her first step out of the boat.

\section{A Translated Text of the Matthayomsuksa 6/4 Student in Number 1}

Katherine thought Justin raft is quiet as before her come, but she found it have many his servant, they squat and waited to greet since she got off the boat. Weerapong

The word choice and grammatical errors of the translated text of the Matthayomsuksa 6/4 student in number 1 is shown in Table 1. 
Table 1: Problematic points, frequency, errors, and correctness of the translated text of the Matthayomsuksa $6 / 4$ student in number 1

\begin{tabular}{|c|l|c|c|c|}
\hline No. & \multicolumn{1}{|c|}{ Problematic Points } & Freq & $\begin{array}{c}\text { Student's } \\
\text { Errors }\end{array}$ & Teacher's Correctness \\
\hline 1. & Word Choice & 1 & thought & Imagined \\
\hline 2. & Possessive's & 1 & Justin & Justin's \\
\hline 3. & Comparative Adjective & 1 & quiet as & might as \\
\hline 4. & Tense & 4 & is, come, have, squat & she \\
\hline 5. & Pronoun & 1 & her & squatted \\
\hline 6. & Singular and Plural Nouns & 1 & servant & while \\
\hline 7. & Conjunction & 1 & since & She was taking her first step out of the boat. \\
\hline 8. & Missing Some Words & 1 & She got off the boat. & she the most at points. \\
\hline
\end{tabular}

From the problematic points of the student in number 1, the student made errors in Tense the most at 4 points. For the rest, the student made errors evenly at 1 point in Word Choice, Possessive's, Comparative Adjective, Pronoun, Singular and Plural Nouns, Conjunction, and Missing Some Words.

Text 2 in Thai: ทุกคนมองเธอราวกับเป็นตัวประหลาด แต่แล้วเมื่อแคธรีนมองตอบพวกเขาก็ก้มหน้าลงต่ำ หลบตา ไม่ยอมประสานสายตาด้วย ข้อนี้ถือเป็นมารยาทของชาวสยามที่จะไม่สบตาผู้อยู่ในฐานะสูงศักดิ์กว่า

Text 2 in English: Everyone looked at her as if she were a freak. But then, when Katherine looked back at them, they bent down their heads, lowered their eyes, and avoided eye contact. This was regarded as a Siamese manner which they did not make eye contact with people who have a higher status than them.

\section{A Translated Text of the Matthayomsuksa 6/4 Student in Number 2}

everyone see to he like a monster But When Katherine see back they are Bown down and prooping refuse to look at her face this request is considered country of siam not to meet the eye of the highter Baiboon

The word choice and grammatical errors of the translated text of the Matthayomsuksa 6/4 student in number 2 is shown in Table 2.

Table 2: Problematic points, frequency, errors, and correctness of the translated text of the Matthayomsuksa 6/4 student in number 2

\begin{tabular}{|c|c|c|c|c|}
\hline No. & Problematic Points & Freq & Student's Errors & Teacher's Correctness \\
\hline 1. & $\begin{array}{l}\text { Capital and Small } \\
\text { Letters }\end{array}$ & 5 & everyone, this, siam, But, When & Everyone, This, Siam, but, when \\
\hline 2. & Word Choice & 9 & $\begin{array}{l}\text { like, a monster, see to, see back, } \\
\text { Bown down, prooping, refuse to } \\
\text { look at, is considered, country of } \\
\text { siam }\end{array}$ & $\begin{array}{l}\text { looked like, a freak, looked at, } \\
\text { looked back, bent down, lowered } \\
\text { their eyes, avoided eye contact, } \\
\text { was regarded as, a Siamese } \\
\text { manner }\end{array}$ \\
\hline 3. & Pronoun & 1 & he & her \\
\hline 4. & Full Stop (.) & 1 & ... her face & ... her face. \\
\hline 5. & Misspelling & 1 & the highter & the higher \\
\hline 6. & Missing Some Words & 1 & the highter & people who have a higher status. \\
\hline
\end{tabular}

From the problematic points of the student in number 2, the student made errors in Word Choice the most at 9 points. Next, the student made errors in Capital and Small Letters at 5 points. For the rest, the student made errors evenly at 1 point in Pronoun, Full Stop ( . ), Misspelling, and Missing Some Words.

Text 3 in Thai: มีแต่รอยยิ้มของชายหนุ่มเท่านั้น ที่ทำให้ความอึดอัดของเธอเบาบางลง จัสตินลุกขึ้นจากตั่งเตี้ยๆ ในห้องด้านนอก ตรงเข้ามาจับมือเธอไว้ สายตาเขาที่มองเธอเต็มไปด้วยความรักและความปิติ

Text 3 in English: There was only a young man's smile which could make her frustration relieve. Justin stood up from a low stool and held her hand in the across room outside. The eyes that he looked at her were full of love and happiness.

A Translated Text of the Matthayomsuksa 6/4 Student in Number 3

Only the smile of a young man that made her happier Justine rise from the low stool in the outside room straight in to hold her hand. His eye that looked at her filled with love and joy. Saharat

The word choice and grammatical errors of the translated text of the Matthayomsuksa 6/4 student in number 3 is shown in Table 3. 
Table 3: Problematic points, frequency, errors, and correctness of the translated text of the Matthayomsuksa 6/4 student in number 3

\begin{tabular}{|c|c|c|c|c|}
\hline No. & Problematic Points & Freq & Student's Errors & Teacher's Correctness \\
\hline 1. & $\begin{array}{l}\text { Adding Unnecessary } \\
\text { Words }\end{array}$ & 1 & that & blank ( ) \\
\hline 2. & Full Stop (. ) & 1 & ... made her happier & ... made her happier. \\
\hline 3. & Tense & 1 & rise & rose \\
\hline 4. & Word Order & 1 & $\begin{array}{l}\ldots \text { in the outside room straight in to } \\
\text { hold her hand. }\end{array}$ & $\begin{array}{l}\ldots \text { and held her hand in the across } \\
\text { room outside. }\end{array}$ \\
\hline 5. & $\begin{array}{l}\text { Singular and Plural } \\
\text { Nouns }\end{array}$ & 1 & His eye & His eyes \\
\hline 6. & $\begin{array}{l}\text { Active and Passive } \\
\text { Voice }\end{array}$ & 1 & were filled & filled \\
\hline
\end{tabular}

From the problematic points of the student in number 3, the student made errors evenly at 1 point in Adding Unnecessary Words, Full Stop ( . ), Tense, Word Order, Singular and Plural Nouns, and Active and Passive Voice.

Text 4 in Thai: “ข อ ต้อน รับ สู่ บ้าน ข องเรา ย อดรัก" เข าจูงมื อ เธ อ ไป นั่งบน ตั่งคู่ กับ เขา “ก่ อ น อื่น คุณต้องรู้จักคนของผมเสียก่อน"

Text 4 in English: "Welcome to our home, darling", he held her hand and took her to sit on the stool together with him. "Firstly, you have to know my people", he said.

\section{A Translated Text of the Matthayomsuksa 6/4 Student in Number 4}

"Welcome to our home, Darling" he held her hand to sit on the stool with him "Firstly, You must know my people" Jitpanu

The word choice and grammatical errors of the translated text of the Matthayomsuksa $6 / 4$ student in number 4 is shown in Table 4.

Table 4: Problematic points, frequency, errors, and correctness of the translated text of the Matthayomsuksa 6/4 student in number 4

\begin{tabular}{|c|c|c|c|c|}
\hline No. & Problematic Points & Freq & Student's Errors & Teacher's Correctness \\
\hline 1. & $\begin{array}{llr}\begin{array}{l}\text { Capital } \\
\text { Letters }\end{array} & \text { and } & \text { Small } \\
\end{array}$ & 2 & Darling, You & darling, you \\
\hline 2. & Comma (, ) & 1 & $\begin{array}{l}\text { "Welcome to our home, darling" } \\
\text { he held her hand ... }\end{array}$ & $\begin{array}{l}\text { "Welcome to our home, darling", } \\
\text { he held her hand ... }\end{array}$ \\
\hline 3. & Missing Some Words & 1 & $\begin{array}{l}\text { he held her hand to sit on the } \\
\text { stool with him }\end{array}$ & $\begin{array}{l}\text { he held her hand and took her to } \\
\text { sit on the stool with him }\end{array}$ \\
\hline 4. & Full Stop (. ) & 2 & $\begin{array}{l}\ldots \text { to sit on the stool with him } \\
\ldots \text { know my people" }\end{array}$ & $\begin{array}{l}\ldots \text { to sit on the stool with him. } \\
\ldots \text { know my people." }\end{array}$ \\
\hline
\end{tabular}

From the problematic points of the student in number 4 , the student made the most evenly errors at 2 points in Capital and Small Letters and Full Stop ( . ). For the rest, the student made errors evenly at 1 point in Comma (, ) and Missing Some Words.

Text 5 in Thai: บริวารของจัสตินมีมากมายจนแคธรีนจำไม่ได้ว่าใครเป็นใคร แม้ว่าแคธรีนเริ่มเข้าใจดีว่า

Text 5 in English: There were so many Justin's servants that Katherine could not remember who was whom. Although Katherine started to understand that

\section{A Translated Text of the Matthayomsuksa 6/4 Student in Number 5}

Justin's servants were so many that Kathryn could not remember who was whom. However, Kathryn began to understand that Nithinart

The word choice and grammatical errors of the translated text of the Matthayomsuksa 6/4 student in number 5 is shown in Table 5.

Table 5: Problematic points, frequency, errors, and correctness of the translated text of the Matthayomsuksa 6/4 student in number 5

\begin{tabular}{|c|c|c|c|c|}
\hline No. & Problematic Points & Freq & Student's Errors & Teacher's Correctness \\
\hline 1. & Missing Some Words & 1 & $\begin{array}{l}\text { Justin's servants were so many } \\
\text { that ... }\end{array}$ & $\begin{array}{l}\text { There were so many Justin's } \\
\text { servants that ... }\end{array}$ \\
\hline 2. & & 1 & Kathryn & Katherine \\
\hline 3. & Conjunction & 1 & However, & Although \\
\hline
\end{tabular}

From the problematic points of the student in number 5, the student made errors evenly at 1 point in Missing Some Words, Misspelling, and Conjunction. 
Text 6 in Thai: สยามไม่ใช่ประเทศที่มั่งคั่งด้วยเงินตราอย่างอังกฤษ หากแต่เป็นประเทศที่อุดมสมบูรณ์ด้วยแรงงาน

Text 6 in English: Siam was not a country which had a lot of money like England, but a lot of labors.

A Translated Text of the Matthayomsuksa 6/4 Student in Number 6

Siam wasn't a country that was rich England But it was a labor rich country Chotmanee

The word choice and grammatical errors of the translated text of the Matthayomsuksa 6/4 student in number 6 is shown in Table 6.

Table 6: Problematic points, frequency, errors, and correctness of the translated text of the Matthayomsuksa 6/4 student in number 6

\begin{tabular}{|c|l|c|c|c|}
\hline No. & Problematic Points & Freq & \multicolumn{1}{|c|}{ Student's Errors } & \multicolumn{1}{|c|}{ Teacher's Correctness } \\
\hline 1. & $\begin{array}{l}\text { Missing Some } \\
\text { Words }\end{array}$ & 1 & $\begin{array}{l}\text { Siam wasn't a country that } \\
\text { was rich England }\end{array}$ & $\begin{array}{l}\text { Siam was not a country which had a lot of } \\
\text { money like England }\end{array}$ \\
\hline 2. & Comma (, ) & 1 & But & , but \\
\hline 3. & $\begin{array}{l}\text { Capital and Small } \\
\text { Letters }\end{array}$ & 1 & But & ... rich country. \\
\hline 4. & Full Stop (.) & 1 & ... rich country & \\
\hline
\end{tabular}

From the problematic points of the student in number 6 , the student made errors evenly at 1 point in Missing Some Words, Comma (, ), Capital and Small Letters, and Full Stop ( . ).

Text 7 in Thai: เธอก็ยังทำความเข้าใจยากอยู่นั่นเองว่าบรรดามหาดเล็กผู้ชาย และนางข้าหลวงผู้หญิงเหล่านี้มีหน้าที่อะไรบ้าง Text 7 in English: It was still difficult for her to understand what all these male and female servants were responsible for.

\section{A Translated Text of the Matthayomsuksa 6/4 Student in Number 7}

She was difficult to understand what male servants and female servants are responsible for everyone. Suchada The word choice and grammatical errors of the translated text of the Matthayomsuksa 6/4 student in number 7 is shown in Table 7.

Table 7: Problematic points, frequency, errors, and correctness of the translated text of the Matthayomsuksa 6/4 student in number 7

\begin{tabular}{|c|l|c|l|l|l|}
\hline No. & \multicolumn{1}{|c|}{ Problematic Points } & Freq & \multicolumn{1}{|c|}{ Student's Errors } & \multicolumn{1}{c|}{ Teacher's Correctness } \\
\hline 1. & Missing Some Words & 2 & $\begin{array}{l}\text { She was difficult to } \\
\text { understand ... } \\
\ldots \text { what male servants and } \\
\text { female servants ... }\end{array}$ & $\begin{array}{l}\text { She was still difficult to } \\
\text { understand.. } \\
\ldots \text { what all these male servants } \\
\text { and female servants ... }\end{array}$ \\
\hline 2. & Tense & 1 & \multicolumn{1}{|c|}{ are } & \multicolumn{1}{c|}{ were } \\
\hline
\end{tabular}

From the problematic points of the student in number 7, the student made errors in Missing Some Words the most at 2 points. For the rest, the student made errors at 1 point in Tense.

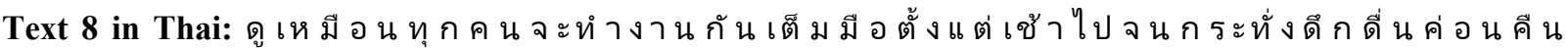
แต่การจัดระเบียบงานก็ยังวุ่นวายให้เธอสับสนอยู่นั่นเอง

Text 8 in English: It seemed to her that everyone had their hands full from the early morning to almost the whole night, but she was still confused with how she would organize the busy work.

\section{A Translated Text of the Matthayomsuksa 6/4 Student in Number 8}

Seems to be working with their hands full from morning to late at night, But the organization of work was still chaotic. Jiranan

The word choice and grammatical errors of the translated text of the Matthayomsuksa 6/4 student in number 8 is shown in Table 8.

Table 8: Problematic points, frequency, errors, and correctness of the translated text of the Matthayomsuksa 6/4 student in number 8

\begin{tabular}{|c|l|c|l|l|}
\hline No. & Problematic Points & Freq & \multicolumn{1}{|c|}{ Student's Errors } & \multicolumn{1}{c|}{ Teacher's Correctness } \\
\hline 1. & Sentence Parts & 1 & Seems to be .. & It seemed to her that ... \\
\hline 2. & Missing Some Words & 2 & $\begin{array}{l}\text { Seems to be working with their } \\
\text { hands full from morning to late } \\
\text { at night } \\
\text { the organization of work was } \\
\text { still chaotic. }\end{array}$ & $\begin{array}{l}\text { It seemed to her that everyone had } \\
\text { their hands full from the early } \\
\text { morning to almost the whole night } \\
\text { She was still confused with how } \\
\text { she would organize the busy work. }\end{array}$ \\
\hline 3. & $\begin{array}{l}\text { Capital and Small } \\
\text { Letters }\end{array}$ & 1 & \multicolumn{1}{c|}{, But but } \\
\hline
\end{tabular}

From the problematic points of the student in number 8, the student made errors in Missing Some Word the most at 2 points. For the rest, the student made errors evenly at 1 point in Sentence Parts and Capital and Small Letters. 
Text 9 in Thai: จัสตินเดาความรู้สึกในสีหน้าของหญิงสาวได้ เขาจึงหัวเราะขันๆ และตัดบท

Text 9 in English: Justin guessed how she was feeling from her face, so he laughed and interrupted,

A Translated Text of the Matthayomsuksa 6/4 Student in Number 9

Justin could guess the feelings in the girl's expression so he laughed jokingly and interrupted. Apatsara

The word choice and grammatical errors of the translated text of the Matthayomsuksa 6/4 student in number 9 is shown in Table 9.

Table 9: Problematic points, frequency, errors, and correctness of the translated text of the Matthayomsuksa 6/4 student in number 9

\begin{tabular}{|c|c|c|c|c|}
\hline No. & Problematic Points & Freq & Student's Errors & Teacher's Correctness \\
\hline 1. & Comma (, ) & 1 & so & , so \\
\hline
\end{tabular}

From the problematic point of the student in number 9, the student made an error in only Comma (, ) at 1 point.

Text 10 in Thai: “คุ ณ ไม่ ต้องยุ่งยาก ใจมาก ต อ แ แ ๆ จะมีหวน กับ คำรับ คำสั่งจากคุ ณ ผมเรียกพวกนี้มาเพื่อให้รู้ว่าเขาเป็นบ่าวไพร่ของคุณ คุณเป็นนายของพวกเขาเช่นเดียวกับผม คุณจะใช้งานใครก็ได้ทั้งหมด" Text 10 in English: "You don't need to be upset. In the beginning, Huan and Kam will take orders from you. I asked them to make you aware that they are your servants. You are their head as well as me. You can employ them all."

A Translated Text of the Matthayomsuksa 6/4 Student in Number 10

You don't feel uncomfortable. At first will have servants follow orders from you. I called them for know they are your servants You've them the same boss as me You can use anyone. Lucksanaporn

The word choice and grammatical errors of the translated text of the Matthayomsuksa 6/4 student in number 10 is shown in Table 10.

Table 10: Problematic points, frequency, errors, and correctness of the translated text of the Matthayomsuksa $6 / 4$ student in number 10

\begin{tabular}{|c|l|c|l|l|}
\hline No. & \multicolumn{1}{|c|}{ Problematic Points } & Freq & \multicolumn{1}{|c|}{$\begin{array}{c}\text { Student's } \\
\text { Errors }\end{array}$} & \multicolumn{1}{|c|}{ Teacher's Correctness } \\
\hline 1. & Double Negative & 1 & You don't feel uncomfortable. & You feel uncomfortable. \\
\hline 2. & Sentence Parts & 1 & will have servants. & $\begin{array}{l}\text { There will be servants ... } \\
\text { Huan and Kam will take orders } \\
\text { from you. }\end{array}$ \\
\hline 3. & Participial Phrase & 1 & $\begin{array}{l}\text { There will be servants follow } \\
\text { orders from you. }\end{array}$ & $\begin{array}{l}\text { There will be servants following } \\
\text { orders from you. }\end{array}$ \\
\hline 4. & Gerund & 1 & I called them for know ... & I called them for knowing that ... \\
\hline 5. & Full Stop (.) & 2 & $\begin{array}{l}\ldots \text { they are your servants } \\
\ldots \text { the same boss as me }\end{array}$ & $\begin{array}{l}\text {. they are your servants. } \\
\ldots \text { the same boss as me. }\end{array}$ \\
\hline 6. & Missing Some Words & 1 & You've them the same boss... & You've them as the same boss... \\
\hline 7. & Possessive Pronoun & 1 & $\ldots$ the same boss as me. & $\ldots$ the same boss of mine. \\
\hline
\end{tabular}

From the problematic points of the student in number 10, the student made errors in Full Stop ( . ) the most at 2 points. For the rest, the student made errors evenly at 1 point in Double Negative, Sentence Parts, Participial Phrase, Gerund, Missing Some Words, and Possessive Pronoun.

Text 11 in Thai:

เธอจะใช้งานอะไรกับผู้คนที่เธอพูดภาษาของเขาไม่ได้กี่คำ....ผู้คนที่เอาแต่หมอบคลานอยู่บนพื้นในขณะที่เธอยืนตัวตรง $\ldots . .$. และ ดูเหมือนเขาจะพากันนั่งเฝ้าเธอเต็มไปหมดไม่ว่าเธอจะขยับเขยื้อนไปมุมไหนของห้อง

Text 11 in English: How could she employ the people with whom she could speak so few words with... and with the people who were squatting on the ground, in spite of seeing her standing up straight... and it appeared to her that they all were sitting and watching over her no matter where she was moving in the room.

A Translated Text of the Matthayomsuksa 6/4 Student in Number 11

How could she employ with the people whom can speak a few word. The people squatting on floor in spite of her standing up straight and it seemed that they were sitting and watching over her no matter where she was moving in the room. Kunthad

The word choice and grammatical errors of the translated text of the Matthayomsuksa 6/4 student in number 11 is shown in Table 11. 
Table 11: Problematic points, frequency, errors, and correctness of the translated text of the Matthayomsuksa $6 / 4$ student in number 11

\begin{tabular}{|c|l|c|l|l|}
\hline No. & \multicolumn{1}{|c|}{ Problematic Points } & Freq & \multicolumn{1}{|c|}{$\begin{array}{c}\text { Student's } \\
\text { Errors }\end{array}$} & \multicolumn{1}{|c|}{ Teacher's Correctness } \\
\hline 1. & Word Order & 1 & $\begin{array}{l}\text { How could she employ with the } \\
\text { people whom ... }\end{array}$ & $\begin{array}{l}\text { How could she employ the people } \\
\text { with whom ... }\end{array}$ \\
\hline 2. & Tense & 1 & can & could \\
\hline 3. & Sentence Parts & 2 & $\begin{array}{l}\text { with whom could speak so few } \\
\text { words. } \\
\text { The people squatting on floor ... }\end{array}$ & $\begin{array}{l}\text { with whom she could speak so } \\
\text { few words. } \\
\text { The people squatted on floor ... }\end{array}$ \\
\hline 4. & Missing Some Words & 1 & $\ldots$ and it seemed that ... & $\ldots$ and it seemed to her that ... \\
\hline
\end{tabular}

From the problematic points of the student in number 11, the student made errors in Sentence Parts the most at 2 points. For the rest, the student made errors evenly at 1 point in Word Order, Tense, and Missing Some Words. From Table 1 to Table 11, every each problematic point, frequency, and percentage of each and all the 11 students of Matthayomsuksa 6/4 is shown in Table 12.

Table 12 shows problematic points, frequency, and percentage of each and all the 11 students of Matthayomsuksa 6/4.

\begin{tabular}{|c|c|c|c|c|c|c|c|c|c|c|c|c|c|c|}
\hline \multirow{2}{*}{ No. } & \multirow{2}{*}{ Problematic Points } & \multicolumn{11}{|c|}{ Students' Numbers } & \multirow{2}{*}{ Total } & \multirow{2}{*}{$\%$} \\
\hline & & 1 & 2 & 3 & 4 & 5 & 6 & 7 & 8 & 9 & 10 & 11 & & \\
\hline 1. & Missing Some Words & 1 & 1 & - & 1 & 1 & 1 & 2 & 2 & - & 1 & 1 & 11 & 15.94 \\
\hline 2. & Word Choice & 1 & 9 & - & - & - & - & - & - & - & - & - & 10 & 14.49 \\
\hline 3. & Capital and Small Letters & - & 5 & - & 2 & - & 1 & - & 1 & - & - & - & 9 & 13.04 \\
\hline 4. & Tense & 4 & - & 1 & - & - & - & 1 & - & - & - & 1 & 7 & 10.14 \\
\hline 5. & Full Stop (. ) & - & 1 & 1 & 2 & - & 1 & - & - & - & 2 & - & 7 & 10.14 \\
\hline 6. & Sentence Parts & - & - & - & - & - & - & - & 1 & - & 1 & 2 & 4 & 5.80 \\
\hline 7. & Comma $()$, & - & - & - & 1 & - & 1 & - & - & 1 & - & - & 3 & 4.35 \\
\hline 8. & Pronoun & 1 & 1 & - & - & - & - & - & - & - & - & - & 2 & 2.90 \\
\hline 9. & Singular and Plural Nouns & 1 & - & 1 & - & - & - & - & - & - & - & - & 2 & 2.90 \\
\hline 10. & Conjunction & 1 & - & - & - & 1 & - & - & - & - & - & - & 2 & 2.90 \\
\hline 11. & Misspelling & - & 1 & - & - & 1 & - & - & - & - & - & - & 2 & 2.90 \\
\hline 12. & Word Order & - & - & 1 & - & - & - & - & - & - & - & 1 & 2 & 2.90 \\
\hline 13. & Possessive's & 1 & - & - & - & - & - & - & - & - & - & - & 1 & 1.45 \\
\hline 14. & Comparative Adjective & 1 & - & - & - & - & - & - & - & - & - & - & 1 & 1.45 \\
\hline 15. & Adding Unnecessary Words & - & - & 1 & - & - & - & - & - & - & - & - & 1 & 1.45 \\
\hline 16. & Active and Passive Voice & - & - & 1 & - & - & - & - & - & - & - & - & 1 & 1.45 \\
\hline 17. & Double Negative & - & - & - & - & - & - & - & - & - & 1 & - & 1 & 1.45 \\
\hline 18. & Participial Phrase & - & - & - & - & - & - & - & - & - & 1 & - & 1 & 1.45 \\
\hline 19. & Gerund & - & - & - & - & - & - & - & - & - & 1 & - & 1 & 1.45 \\
\hline 20. & Possessive Pronoun & - & - & - & - & - & - & - & - & - & 1 & - & 1 & 1.45 \\
\hline & $\begin{array}{c}\text { Total } \\
\end{array}$ & 11 & 18 & 6 & 6 & 3 & 4 & 3 & 4 & 1 & 8 & 5 & 69 & 100 \\
\hline & $\%$ & $\begin{array}{l}15 . \\
94\end{array}$ & $\begin{array}{l}26 . \\
09\end{array}$ & $\begin{array}{l}8 . \\
69\end{array}$ & $\begin{array}{l}8 . \\
69\end{array}$ & $\begin{array}{l}4 . \\
35 \\
\end{array}$ & $\begin{array}{l}5 . \\
80\end{array}$ & $\begin{array}{l}4 . \\
35 \\
\end{array}$ & $\begin{array}{l}5 . \\
80\end{array}$ & $\begin{array}{l}1 . \\
45\end{array}$ & $\begin{array}{l}11 . \\
59\end{array}$ & $\begin{array}{l}7 . \\
25 \\
\end{array}$ & & \\
\hline
\end{tabular}

According to Table 12, the results revealed that in the first place, all the 11 students of Matthayomsuksa 6/4 made an error in Missing Some Words the most at 11 points or $15.94 \%$. In the second place, all the 11 students of Matthayomsuksa 6/4 made an error in Word Choice at 10 points or $14.49 \%$. In the third place, all the 11 students of Matthayomsuksa 6/4 made an error in Capital and Small Letters at 9 points or 13.04\%. In the fourth place, all the 11 students of Matthayomsuksa $6 / 4$ made errors evenly at 7 points or $10.14 \%$ in Tense and Full Stop (. .). In the fifth place, all the 11 students of Matthayomsuksa 6/4 made an error in Sentence Parts at 4 points or $5.80 \%$. In the sixth place, all the 11 students of Matthayomsuksa $6 / 4$ made an error in Comma $($,$) at 3$ points or $4.35 \%$. In the seventh place, all the 11 students of Matthayomsuksa 6/4 made errors evenly at 2 points or $2.90 \%$ in Pronoun, Singular and Plural Nouns, Conjunction, Misspelling, and Word Order. In the eighth or last place, all the 11 students of Matthayomsuksa 6/4 made errors evenly at 1 point or $1.45 \%$ in Possessive's, Comparative Adjective, Adding Unnecessary Words, Active and Passive Voice, Double Negative, Participial Phrase, Gerund, and Possessive Pronoun.

Besides, from Table 12, the results demonstrated that in the first place, the student in number 2 made errors the most at 18 points or $26.09 \%$. In the second place, the student in number 1 made errors at 11 points or $15.94 \%$. In the third place, the student in number 10 made errors at 8 points or $11.59 \%$. In the fourth place, the student in 
number 3 and the student in number 4 made errors at 6 points or $8.69 \%$. In the fifth place, the student in number 11 made errors at 5 points or $7.25 \%$. In the sixth place, the student in number 6 and the student in number 8 made errors at 4 points or $5.80 \%$. In the seventh place, the student in number 5 and the student in number 7 made errors at 3 points or $4.35 \%$. In the eighth or last place, the student in number 9 made the least error at 1 point or $1.45 \%$.

As shown in Table 12, in translating and writing English, mostly, 11 Matthayomsuksa 6/4 students made errors in the first 5 sequences of the following problematic points: 1.11 points or $15.94 \%$ of Missing Some Words, 2.10 points or $14.49 \%$ of Word Choice, 3. 9 points or $13.04 \%$ of Capital and Small Letters, 4.7 points or $10.14 \%$ of Tense and Full Stop ( . ) which also has the same 7 points or $10.14 \%, 5$. 4 points or $5.80 \%$ of Sentence Parts. Therefore, to improve 11 high-school students of Matthayomsuksa 6/4 in the English-Japanese Program, the teacher-researcher should develop the students in these first 6 problematic points which the students made the most in the first 5 sequences.

\section{Discussion}

About the results of an analysis of English word choice and grammatical errors in Thai novel translation of 11 Matthayomsuksa 6/4 students in the English-Japanese Program, the research results will be discussed as follows. 6.1. To have much higher reliability of the data analysis, the teacher-researcher should have all the 11 students translate the same text. For the group of middle achieving students, the text "ขอต้อนรับสูบ้านของเรา ยอดรัก" เขาจูงมือเธอไปนั่งบนตั่งคู่กับเขา “ก่อนอื่น คุณต้องรู้จักคนของผมเสียก่อน" ("Welcome to our home, darling", he held her hand and took her to sit on the stool together with him. "Firstly, you have to know my people", he said.) should be used. For the group of high-achieving students, the text “แค ธรีนวาด ภาพว่าที่แพ ข องจัส ติน คง จะเงียบเชียบ เหมือ นครั้งก่อ น ที่ เธอ เคยมาหา แต่ก็กลับพบว่ามันเต็มไปด้วยผู้คนบริวารของเขา หมอบเฝ้ารอรับอยู่ตั้งแต่ก้าวแรกที่เธอขึ้นจากเรือเลยทีเดียว" ("Katherine imagined that at Justine's raft, it might be as quiet as the time she had been before, but she found out that the raft was crowded with servants squatting and waiting to greet her while she was taking her first step out of the boat.") should be used. As a result, when all the 11 students translate the same text, the results of data analysis can present which students are excellent or which students are not. Among all the 11 students translating the same text, it can be also known which students made few errors or which students made a lot of errors.

However, having each student translate and write each different text in this present research can inform the results of data analysis to some extent. For example, it is demonstrated that the first 5 sequences of the problematic points which all the 11 students made the most enable the teacher-researcher to know and develop all the 11 students in these 6 problematic points first. The teacher-researcher can also improve the group of the students or individual students in the problematic points which they made. As an illustration, the students in number 2, 4, 6, and 8 made errors in Capital and Small Letters at 5 points, 2 points, 1 point, and 1 point respectively. Consequently, this group of students needs to improve in Capital and Small Letters the most. Another example is that the student alone in number 2 made errors in Word Choice the most at 9 points. For this reason, this student needs to improve the most in Word Choice. Classroom-based research for improving the group of the students or the individual students in the problematic points can be conducted after this present research.

Additionally, if the data analysis is not counted, translating and writing each different text will make each student read all texts before he or she translates and writes his or her own text assigned by the teacher. In this way, the students will learn all texts more than reading and translating the same one text. It becomes clear to the teacher-researcher that reading all texts before translating and writing his or her own text will enable him or her to learn more than reading, translating, and writing the same one text for the highest reliability of the data analysis.

6.2. Thornbury (2019) indicated on dimensions of methodology. On one hand, the Grammar-Translation Method focuses on form, analysis, accuracy, system, segregation, cognition, transmission, deduction, and bilingualism. On the other hand, Communicative Language Teaching concentrates on function, experience, communication, skills, integration, affection, dialogue, induction, and monolingualism. Panich (2016: 75) suggested applying the Grammar-Translation Method and Communicative Language Teaching. Strong points of each method and weak points of each method can complement each other. In other words, the Grammar-Translation Method can develop learners in reading and writing, while Communicative Language Teaching can develop learners in listening and speaking (Panich, 2016, p. 75). The results of this present research are in line with Eisa (2020: 381392)'s findings in this present Literature Review stating that students cannot master all the four skills of English (listening, speaking, reading, and writing); therefore, instead of using the Grammar-Translation Method, the Eclectic method is suggested.

6.3. The learning and teaching material which is a Wo. Winitchaikun's novel extract "Burapha" under the basic objective of the Grammar-Translation Method enables learners to read literature and learn about native speakers' 
cultures via literature. Reading literature is the original purpose of the Grammar-Translation Method. When the materials are works of literature, the Grammar-Translation Method can be applied (Angwatthanakun 1997).

6.4. In addition to reading literature which is the original purpose of the Grammar-Translation Method, Angwatthanakun (1997) pointed out that the Grammar-Translation Method is appropriate for a large group of students and adults or high-achieving students especially the students who can memorize grammar rules and apply them. As a consequence, this method is not suitable for beginners. It should be used for proficient learners who can use the language very well. In this study, the students translate and make a few or a lot of word choice and grammatical errors depending on the texts as well, for instance, a long text or a short text, a difficult text, and a complicated text or a simple text. It signifies that students need to know and apply words and grammar very well for Thai novel translation which is relevant to the language intellectuals. The results of this present research also concur with Eisa (2020: 381-392)'s study on the bad effect of the Grammar-Translation Method indicated in this present Literature Review. Eisa (2020: 381-392) reported that students cannot succeed in learning the difficult grammar rules of the target language. As a result, the difficult grammar rules of the target language through the Grammar-Translation Method demotivates students. These results are different from Megawati (2017: 95-108)'s study in this present Literature Review giving information on the good effect of the Grammar-Translation Method on reading comprehension. The results of this present research might be prone to Eisa (2020: 381-392)'s study owing to 69 English word choice and grammatical errors in translation of all the 11 students of Matthayomsuksa 6/4. There should not have been a lot of word choice and grammatical errors in the translation of all the 11 students of Matthayomsuksa 6/4. On the results of this study, the very few students or 11 students should not make a lot of word choice and grammatical errors.

\section{Recommendation for Further Research}

Based on the findings of this study, the following recommendation is made for further research.

Further research will study the two classrooms. In one classroom, each student translates a Thai novel extract into English on his or her own. In the other classroom, all the students in the classroom help together to translate the same Thai novel extract as the former classroom into English. The purpose of the further research will study which classroom the students will make few or a lot of English word choice and grammatical errors between the two classrooms.

\section{References}

Angwatthanakun, S. (1997). How to teach English. Bangkok: Chulalongkorn University. [in Thai]

Carroll, J. A., Wilson, E. E., Forlini, G. (2001). Prentice Hall writing and grammar: Communication in action bronze level. Upper Saddle River, N.J.: Prentice Hall.

Dithiyon, W. (2019). Burapha. Bangkok: Arun Press. [in Thai]

Eisa, S. A. H. (2020). The pros and cons of the Grammar Translation Method on the performance of Saudi EFL learners. Arab Journal for Scientific Publishing (AJSP), 2, 381-392.

Graduate School. (2009). Graduate school admission exams year 2009 of reading, translating, and writing an essay. Unpublished manuscript. [in Thai]

Kamying, S. (2010). Advanced English grammar for high learner. Bangkok: Orathai Printing Publisher. [in Thai]

Megawati, M. (2017). The improving students' reading comprehension through Grammar Translation Method (A classroom action research at tenth grade student, even semester 2016/ 2017 academic year at Private Vocational High School TaposDepok). English Education: Journal of English Teaching and Research, 2(2), 95-108.

Murphy, R. (1998). English grammar in use: A self-study reference and practice book for intermediate students: with answers. Cambridge: Cambridge University Press.

Panich, R. (2016). Teaching second language according to Grammar-Translation Method. Journal of Humanities, Naresuan University, 13(1), 67-77. [in Thai]

Sittirak, N. (2015). Grammar-Translation Method in an EFL Class in Thailand: A glance at an English song's lyrics. Journal of Education Thaksin University, 15(2), 30-47.

Thornbury, S. (2019). What's the latest method?. Retrieved from https://m.youtube.com/watch?v=nue 8AN99XsuY\&t $=1851$.

Youngsathian, P. (2017). New weaving it together 3 teacher's guide. Bangkok: Thai Watana Panich Co. Ltd. [in Thai] 
Appendix A

ข้อสอบเข้าบัณฑิตวิทยาลัย ปีการศึกษา 2552

วันที่ 16 มีนาคม 2552

\section{บัณฑิตวิทยาลัย}

ข้อสอบหมวดวิชาการอ่าน การแปลและ

การเขียนเรียงความ

เวลา $09.00-12.00$ น.

3 hours

ข้อสอบฉบับนี้มีทั้งหมด 4 หน้า

300 points

Part I Translation (100 points)

1. Translation : Thai -English (50 points)

Translate the following into English on the answer sheet.

แค ธรีนวาด ภาพว่าที่แพข องจัสตินคงจะเงียบเชียบเหมือนครั้งก่อนที่เธอเคยมาหา แต่ก็กลับพบว่ามันเต็มไปด้วยผู้คนบริวารของเขา หมอบเฝ้ารอรับอยู่ตั้งแต่ก้าวแรกที่เธอขึ้นจากเรือเลยทีเดียว

ทุกคนมองเธอราวกับเป็นตัวประหลาด แต่แล้วเมื่อแคธรีนมองตอบพวกเขาก็ก้มหน้าลงต่ำ หลบตา

ไม่ยอมประสานสายตาด้วย ข้อนี้ถือเป็นมารยาทของชาวสยามที่จะไม่สบตาผู้อยู่ในฐานะสูงศักดิ์กว่า

มีแต่รอยยิ้มของชายหนุ่มเท่านั้น ที่ทำให้ความอึดอัดของเธอเบาบางลง จัสตินลุกขึ้นจากตั่งเตี้ยๆ ในห้องด้านนอก

ตรงเข้ามาจับมือเธอไว้ สายตาเขาที่มองเธอเต็มไปด้วยความรักและความปิติ

“ขอต้อนรับสูบ้านของเรา ยอดรัก" เขาจูงมือเธอไปนั่งบนตั่งคู่กับเขา “ก่อนอื่น คุณต้องรู้จักคนของผมเสียก่อน”

บริวารของจัสตินมีมากมายจนแคธรีนจำไม่ ได้ว่าใครเป็นใคร แม้ว่าแคธรีนเริ่ม เข้าใจดีว่า

สยาม ไม่ ใช่ประเท ศ ที่งั่งคั่งด้วย เงินตราอย่างอังกฤษ หากแต่ เป็นประเท ศที่ อุดมสม บู รณ์ ด้วย แรงงาน เธอก็ยังทำความเข้าใจยากอยู่นั่นเองว่าบรรดามหาดเล็กผู้ชาย และนางข้าหลวงผู้หญิงเหล่านี้มีหน้าที่อะไรบ้าง ดูเหมือนทุกคนจะทำงานกันเต็มมือตั้งแต่เช้าไปจนกระทั่งดึกดื่นค่อนคืน แต่การจัดระเบียบงานก็ยังวุ่นวายให้เธอสับสนอยู่นั่นเอง จัสตินเดาความรู้สึกในสีหน้าของหญิงสาวได้ เขาจึงหัวเราะขันๆ และตัดบท

“คุ ณ ไม่ ต้องยุ่งยากใจมาก ต อ แ รกๆ จะมีหวน กับคำ รับ คำสั่งจาก คุ ณ ผมเรียกพวกนี้มาเพื่อให้รู้ว่าเขาเป็นบ่าวไพร่ของคุณ คุณเป็นนายของพวกเขาเช่นเดียวกับผม คุณจะใช้งานใครก็ได้ทั้งหมด" เธอจะใช้งานอะไรกับผู้คนที่เธอพูดภาษาของเขาไม่ได้กี่คำ....ผู้คนที่เอาแต่หมอบคลานอยู่บนพื้นในขณะที่เธอยืนตัวต รง....และดูเหมือนเขาจะพากันนั่งเฝ้าเธอเต็มไปหมดไม่ว่าเธอจะขยับเขยื้อนไปมุมไหนของห้อง

$$
\begin{aligned}
& \text { จาก นวนิยายเรื่อง บูรพา } \\
& \text { ของ ว. วินิจฉัยกุล }
\end{aligned}
$$

\section{Appendix B}

\section{A Translation of A Wo. Winitchaikun's Novel Extract "Burapha"}

Katherine imagined that at Justine's raft, it might be as quiet as the time she had been before, but she found out that the raft was crowded with servants squatting and waiting to greet her while she was taking her first step out of the boat.

Everyone looked at her as if she were a freak. But then, when Katherine looked back at them, they bent down their heads, lowered their eyes, and avoided eye contact. This was regarded as a Siamese manner which they did not make eye contact with people who have a higher status than them.

There was only a young man's smile which could make her frustration relieve. Justin stood up from a low stool and held her hand in the across room outside. The eyes that he looked at her were full of love and happiness.

"Welcome to our home, darling", he held her hand and took her to sit on the stool together with him. "Firstly, you have to know my people", he said.

There were so many Justin's servants that Katherine could not remember who was whom. Although Katherine started to understand that Siam was not a country which had a lot of money like England, but a lot of labors. It was still difficult for her to understand what all these male and female servants were responsible for. It seemed to her that everyone had their hands full from the early morning to almost the whole night, but she was still confused with how she would organize the busy work.

Justin guessed how she was feeling from her face, so he laughed and interrupted,

"You don't need to be upset. In the beginning, Huan and Kam will take orders from you. I asked them to make you aware that they are your servants. You are their head as well as me. You can employ them all."

How could she employ the people with whom she could speak so few words with... and with the people who were squatting on the ground, in spite of seeing her standing up straight... and it appeared to her that they all were sitting and watching over her no matter where she was moving in the room. 
From "Burapha"

By Wo. Winitchaikun

Translated by Thoseporn

Proofread by Thomas Philip Hoskisor

Researcher's Profile

Name

Address

Mobile

Email Address

Office

Educational Background Bachelor of Education Master of Arts
Thoseporn Sophitthammakun

458/3 Thanapirom Soi Phetkasem 69 Nongkhaem sub-district, Nongkhaem District Bangkok 10160 090-423-0927

Thosepornssophitthammakun@gmail.com

Foreign Languages Department, Panyaworakun School, SESAO 1
Bachelor of Education (English) Faculty of Education, Chulalongkorn University

Master of Arts (Teaching English as a Foreign Language)

Language Institute, Thammasat University 